\title{
WestVirginiaUniversity
}

THE RESEARCH REPOSITORY @ WVU

Graduate Theses, Dissertations, and Problem Reports

2009

\section{Body image and celebrity tabloids}

\author{
Sarah Young \\ West Virginia University
}

Follow this and additional works at: https://researchrepository.wvu.edu/etd

\section{Recommended Citation}

Young, Sarah, "Body image and celebrity tabloids" (2009). Graduate Theses, Dissertations, and Problem Reports. 4553.

https://researchrepository.wvu.edu/etd/4553

This Thesis is protected by copyright and/or related rights. It has been brought to you by the The Research Repository @ WVU with permission from the rights-holder(s). You are free to use this Thesis in any way that is permitted by the copyright and related rights legislation that applies to your use. For other uses you must obtain permission from the rights-holder(s) directly, unless additional rights are indicated by a Creative Commons license in the record and/ or on the work itself. This Thesis has been accepted for inclusion in WVU Graduate Theses, Dissertations, and Problem Reports collection by an authorized administrator of The Research Repository @ WVU. For more information, please contact researchrepository@mail.wvu.edu. 
BODY IMAGE AND CELEBRITY TABLOIDS

\author{
Sarah Young \\ Thesis submitted to the \\ Perley Isaac Reed School of Journalism \\ at West Virginia University \\ in partial fulfillment of the requirements \\ for the degree of \\ Master of Science \\ in \\ Journalism \\ John Temple, M.F.A. \\ Donald Hall, Ph.D. \\ Ivan Pinnell, Ph.D. \\ Gina Dahlia M.S.J.
}

School of Journalism

Morgantown, West Virginia

2009

Keywords: Celebrity, Body Image, Tabloid 


\section{ABSTRACT}

\section{Sarah Young}

This research aims to find a relationship between celebrity-obsessed tabloids, and the effect on body image of women ages 18-24 living in West Virginia, versus outside the state of West Virginia, based on a numeric scale. 


\section{TABLE OF CONTENTS}

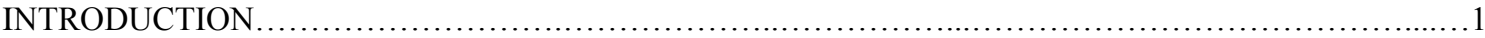

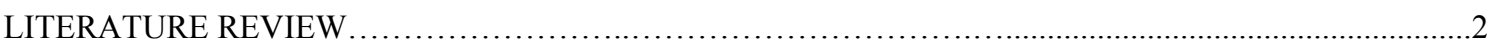

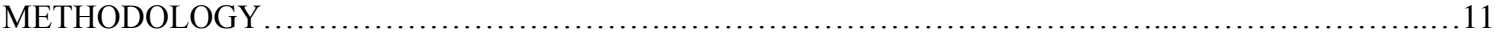

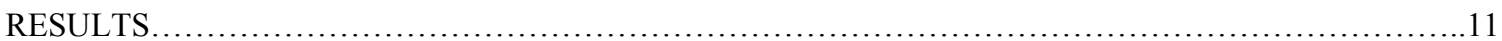

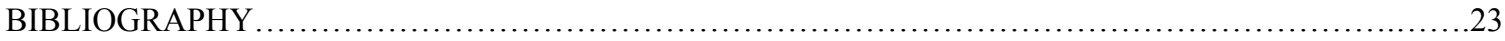




\section{INTRODUCTION}

This research will focus on college-aged women (18-24) and the effects on body image that celebritydriven magazines provide. ${ }^{1}$ The research will determine if West Virginia female residents between the ages 18-24 are less affected by the images in celebrity-driven magazines than females of the same age that are from outside the state.

I believe that this research will show West Virginia female residents between the ages of 18-24 to be less affected by celebrity-driven magazines. They will be less likely to read them, have their body image affected, and less likely to be more critical of other women's bodies. The reason for my presumption is the abundance of obesity in the state of West Virginia. ${ }^{2}$ I feel that young women from West Virginia who read celebrity-driven magazines will see the ultra-thin celebrities being photographed, but then be offset by the amount of overweight people they see living in their state, and not be as critical of themselves.

“Obesity has increased statewide over the past decade throughout West Virginia. In 1990, the West Virginia rate was $15.0 \%$, compared with the U.S. rate of $11.6 \%$. By 2000 , the West Virginia rate was $23.2 \%$, compared with $20.1 \%$ for the nation as a whole."3

The focus of this research is body image and the effects celebrity-driven magazines have on how women between the ages of 18-24 view their own bodies. I began taking an interest in this subject as a thesis topic my first year of graduate school. I have friends who have suffered through mild to severe eating disorders, starting in high school. I also noticed that many of these young women (as well as myself) read celebrity-obsessed magazines such as Us Weekly, OK, and Star. According to Us Weekly, the magazine sells over 2 million copies a week, that number includes people who have a subscription ${ }^{4}$. Over 70 percent of readers are women, over 25 percent between the ages $18-24 .^{5}$ When I read these magazines I notice the amount of female actresses and models that are noticeably underweight and idolized for their beauty and physique.

\footnotetext{
${ }^{1}$ http://www.srds.com/mediakits/us weekly/demographics.html

${ }^{2}$ http://www.wvdhhr.org/bph/oehp/obesity/section2.htm

${ }^{3}$ Ibid

${ }^{4}$ http://www.srds.com/mediakits/us_weekly/demographics.html

${ }^{5}$ http://www.echo-media.com/mediadetail.asp?IDNUmber=5333
} 
Every time I see the actresses in Us Weekly, I cannot help but compare myself and then, in turn, be more critical of others and myself.

My goal was to gather more information regarding body image issues and young women and determine whether there is a correlation between reading celebrity tabloids and becoming more critical of one's own appearance as well as that of other women. The survey will also determine whether, within my sample, women from the state of West Virginia are less likely than women from out of state to read celebrity tabloids.

\section{LITERATURE REVIEW}

This literature review is divided into three sections: Problem Statement, Body Image, and Theory.

\section{PROBLEM STATEMENT}

More than 90 percent of women will diet at some point in their lifetime, and more than 70 percent are unhappy about their physical appearance. ${ }^{6}$

Girls as young as five years old place an importance on body image and weight that effects their selfesteem and body confidence throughout a lifetime ${ }^{7}$. The significance of being thin is reflected by popularity among peers and acceptance of one's body physically and psychologically ${ }^{8}$.

The amount of images of super-thin celebrities is overwhelming. It is impossible to walk into a supermarket without being bombarded by celebrity-driven magazines ${ }^{9}$. According to Renee Botta, "Magazines reinforce the rewards that accompany the attainment of "perfect" bodies. Four hundred high school and college students were surveyed to test the extent to which reading magazines increased eating disorders. Results indicate that magazine reading, social comparisons, and critical body image processing are important predictors of body image and eating disturbances for adolescent girls."10

\footnotetext{
${ }^{6}$ Ibid.

${ }^{7}$ Graham, Michelle. (2005). “Wanting To Be Her, Body Image Secrets Victoria Wont Tell You.” (2005). 21-23

${ }^{8}$ Ibid.

${ }^{9}$ Ibid.

${ }^{10}$ Botta, R.A. (2003). "For Your Health? The Relationship between Magazine Reading and Adolescents' Body Image and Eating Disturbances." 389+.
} 
With magazines, movies, and television showing the images of thin, attractive women the images are reinforcing the idea learned as young as five, that physical beauty is an accurate measure of self-worth. ${ }^{11}$ Popular celebrity-driven magazines include: Us Weekly, People, In Touch, Star and OK. An excerpt from Us Weekly's website reads the purpose of the magazine to be:

"Us Weekly is readers' source for breaking celebrity news, Hollywood style and the best in entertainment. Us Weekly engages and indulges its readers, feeding their insatiable appetite for all things celebrity. From the red carpet to retail, US Weekly has extensive coverage of the "musts" in entertainment, fashion and beauty."12

And the images of ultra-thin celebrities gracing the covers of magazines do not appear to be disappearing in the near future. The popularity of celebrity-obsessed magazines like Us Weekly continues to grow. "Wenner Media's Us Weekly is reporting average circulation of 1.75 million over the second half of 2006, up 5 percent. Bauer Publishing's In Touch Weekly and Life \& Style Weekly grew 8 percent to 1.27 million and 25 percent to about 750,000." ${ }^{\prime 14}$ According to Us Weekly demographics More than 70 percent of readers are women, 27 percent of readers are between the ages 18 and 24, 42 percent are single, and 75 percent are white. ${ }^{15}$

The body types of women found gracing the covers of celebrity magazines do not match the body type of the average American women. "The typical American woman is 5'4", weighs 140 pounds, and wears a size 8; the typical fashion model is seven inches taller, twenty-three pounds lighter, and 6 sizes smaller."16 The weight of models in the past 25 years has dropped considerably to the runway models of today. ${ }^{17}$ Even decades ago, models were thinner than the average American woman, and they have become even more underweight over time. ${ }^{18}$

\footnotetext{
${ }^{11}$ Graham, Michelle. (2005). “Wanting To Be Her, Body Image Secrets Victoria Wont Tell You.” (2005). 14.

${ }^{12}$ http://www.echo-media.com/mediadetail.asp?IDNUmber=5333

${ }^{13}$ Ives, N. (2007, February 12). "Going ga-ga over gossip: Celeb mags still soaring.” Advertising Age, 78(7), 4-29. Retrieved December 5, 2008 from Academic Search Complete database.

${ }^{14}$ Ibid.

${ }^{15}$ http://www.srds.com/mediakits/us weekly/demographics.html

${ }^{16}$ Harris, D. (2008, January). “Celebrity Bodies.” Southwest Review, 93(1), 135-144. Retrieved December 10, 2008, from Academic Search Complete database.

${ }^{17}$ Bordo, Susan. "Unbearable Weight, Feminism, Western Culture, And the Body."1995. 57.

${ }^{18}$ Morry, M., \& Staska, S. (2001). Magazine exposure: Internalization, self-objectification, eating attitudes, and body satisfaction in male and female university students. Canadian Journal of Behavioural Science, 33(4), 269-279.
} 
Women are more likely than men to be criticized for their physical appearance, and overweight women are more likely to be discriminated against than males. ${ }^{19}$ But are women contributing to these statistics? Have women become more critical of other women over time?

Through physical forms that seem "perfect," women could start to view themselves as objects that are available to be analyzed in a negative way. Some celebrities have been a target of this kind of negative body exposure and are taking a stand against the tabloids and gossip columns, such as Tyra Banks. When, Banks was photographed wearing a bathing suit and was criticized for her weight gain. Banks fought back on her talk show, showing how images can be taken in an unflattering way, trying to motivate other women to feel better about their own bodies. Banks then went on to lose an estimated 30 pounds after the negative feedback about her body. Women are feeling the pressure of getting and maintaining a body that fits in with the media's portrayal of attractiveness. $^{20}$

\section{BODY IMAGE}

Body image is defined a number of ways. One is a person's perception of his or her physical self, including every aspect of physical characteristics. If someone has a negative perception of his or her physical qualities, it can have an effect on them psychologically. ${ }^{21}$ The way you view your body image directly impacts personal hygiene, sexual habits, exercise, eating patterns and overall self-esteem. ${ }^{22}$

Another way of defining someone's body image is to analyze all thoughts, feelings, beliefs and attitudes about their representation. ${ }^{23}$ These feelings and thoughts can be easily influenced by a number of things, including peers, family, and the media. The medium chosen to analyze in this study are magazines, celebrityobsessed magazines such as Us Weekly.

There have been a growing number of research studies done on the impact of a negative body image. Many researchers believe that a negative body image is associated with body dysmorphic disorder, where a

\footnotetext{
${ }^{19}$ Markey, C. N., \& Markey, P.M. (2005.) Relations between Body Image and Dieting Behaviors An Examination of Gender Differences. Sex Roles: A Journal of Research, 53 (7-8), 519+. Retrieved march 29, 2007.

${ }^{20}$ Bordo, Susan. "Unbearable Weight, Feminism, Western Culture, And the Body."1995. 188.

${ }^{21}$ Cash, T., \& Fleming, E. (2002, May). "The Impact of Body Image Experiences: Development of the Body Image Quality of Life Inventory". International Journal of Eating Disorders, 31(4), 455-460.

${ }^{22}$ Ibid.

${ }^{23}$ Jung, J., \& Forbes, G. (2007, December). "Body Dissatisfaction and Disordered Eating Among College Women In China, South Korea and the United States: Contrasting Predictions From Sociocultural and Feminist Theories." contrasting predictions from sociolcultural and feminist theories. Psychology of Women Quarterly, 31(4), 381-393. Retrieved January 7, 2008, from Academic Search Premier database
} 
physical flaw can become an obsession. ${ }^{24}$ This sometimes leads to women trying any way they can to alter their appearance to make them more attractive. Some methods include plastic surgery, excessive dieting and hair color changes. ${ }^{25}$ Other women seem to let body image play a very small role in their overall happiness and self esteem. The way they are physically has very little disruption in their life because they base their happiness on other factors such as relationships and success.

Women who suffer severely with body image issues are commonly treated for eating disorders and psychological problems. ${ }^{26}$ Around $35 \%$ of women are dieting at one time and a quarter of those women develop severe or non-severe eating disorders. The severe eating disorders can include excessive exercise, diet pills, laxative abuse, anorexia, bulimia, and binging. And with the media's obsession with weight and physical ideals, the body image distress can amplify. ${ }^{27}$ "While anorexia is relatively rare--affecting up to 3.7 percent of the female population at some point in their lifetime--it is the most deadly of all mental diseases. About 5 to 10 percent of anorexics die from it or its complications., 28

Over sixty percent of American women feel so much stress over their current body weight that it can be classified as a psychological problem. ${ }^{29}$ This is known as 'body image distress', where people feel that they are inadequate because of their physical appearance.

In American Fitness, a personal trainer describes how many of her clients have what she describes as jealousy over a celebrities body. Women will come in holding pictures of what they see in celebrity magazines and have unrealistic expectations and goals from their own physique. The trainer stresses how important it is for women to become less celebrity-driven and more realistic about their own bodies. The pictures found in tabloid magazines are giving women complexes about their image, according to this personal trainer. ${ }^{30}$

\footnotetext{
${ }^{24}$ Focusing on Body Image Dissatisfaction. (1999, February). USA Today Magazine, Retrieved February 24, 2008, from Academic Search Premier database

25 Ibid.

${ }^{26}$ Cash, T., \& Fleming, E. (2002, May). The Impact of Body Image Experiences: Development of the Body Image Quality of Life Inventory. International Journal of Eating Disorders, 31(4), 455-460.

${ }^{27}$ Ibid.

${ }^{28}$ Wulff, J., Adato, A., Baker, K., Dagostino, M., Ehrich, K., Seaman, D., et al. (2004, July 26). "Pressure To Be Perfect.” People, 62(4), $72-78$

${ }^{29}$ Devlin, M. (2001, November 7). “Body Image in the Balance.” JAMA: Journal of the American Medical Association, $286(17), 2159$.

30 "Reality Check With Ashley Borden.” (2007, January). American Fitness, Retrieved January 11, 2008, from Academic Search Premier database
} 
In a focus group consisting of young women around 19 years old, subjects were placed in an experimental setting and shown images of thin women commonly found in popular magazines. Their change in attitude after exposure to these images pointed to a drop in body confidence. ${ }^{31}$ This proves the vulnerability of women in this age group, which is why women between the ages of 18-24 will be asked questions about the effects of celebritydriven media in this research.

"According to the American Society for Aesthetic Plastic Surgery, 11,326 girls aged 18 and under got breast implants last year--triple the number from 2002."32 Women have taken drastic measures to look more like the images they see in the media.

Men, although considered more overweight (according to their body mass index) than women, tend to have higher body satisfaction. In a research study both sexes were prone to take part in a diet if they were dissatisfied with their current weight and shape. ${ }^{33}$ But according to research men were more likely to participate in unhealthy dieting techniques when they were overweight, while women engaged in these practices in order to measure up to an unrealistic standard of beauty. ${ }^{34}$ The motivation for dieting varied widely according to gender. Men were more likely to diet (even in unhealthy ways) in response to medical necessity, while women within a healthy weight range took part in unhealthy dieting practices to achieve a personal weight goal. ${ }^{35}$

This proves the coercive effect of dominant media images that equate being thin with beauty and perfection on women in our culture. The thin body has become the ideal for females. ${ }^{36}$ Sixty years ago, a woman

\footnotetext{
${ }^{31}$ Maltby, J., Giles, D., Barber, L., \& McCutcheon, L. (2005, February). "Intense-personal celebrity worship and body image: Evidence of a link among female adolescents.” British Journal of Health Psychology, 10(1), 17-32. Retrieved February 8, 2008, from Women's Studies International database.

${ }^{32}$ Wulff, J., Adato, A., Baker, K., Dagostino, M., Ehrich, K., Seaman, D., et al. (2004, July 26). "Pressure To Be Perfect.” People, 62(4), 72-78.

${ }^{33}$ Markey, C. N., \& Markey, P.M. (2005.) "Relations between Body Image and Dieting Behaviors: An Examination of Gender Differences.” Sex Roles: A Journal of Research, 53 (7-8), 519+. Retrieved March 29, 2007.

34 Markey, C. N., \& Markey, P.M. (2005.) "Relations between Body Image and Dieting Behaviors: An Examination of Gender Differences.” Sex Roles: A Journal of Research, 53 (7-8), 519+. Retrieved March 29, 2007.

${ }^{35}$ Ibid.

${ }^{36}$ Stice, E., Schupak-Neuberg, E., Shaw, H. E., \& Stein, R. I. (1994). "Relation of media exposure to eating disorder symptomatology: An examination of mediating mechanisms." Journal of Abnormal Psychology, 103, 836-840. sociocultural theory
} 
classified as an ectomorphic body type (extremely thin) was seen as bashful, socially awkward, and timid. ${ }^{37}$

However this stereotype altered around the mid-seventies, when the ectomorphic body type began to be portrayed as the most sexually appealing out of three standard types: ectomorphic, mesomorphic, and endomorphic. ${ }^{38}$

This cultural emphasis on the ectomorph's superiority to other body types is found in fashion magazines, movies, and television. For young women, the pursuit of this ideal can have grave medical consequences.

Women who have an extremely low body weight can be targets for serious health problems, such as infertility and osteoporosis. $^{39}$

In 1992, research was conducted analyzing the differences in advertising between men and women's fashion magazines. The studies showed that there were ten times more advertisements that promoted weight loss in women's fashion magazines compared to men's fashion magazines. Women are thus ten times more likely to develop an eating disorder than a man. ${ }^{40}$

According to Psychology Today, young women who read fitness or health magazines were found to be twice as likely to turn to unhealthy forms of weight control. The most common forms include limiting calories to less than 1,200 a day, abusing laxatives or diet pills, and self-induced vomiting. ${ }^{41}$ With this correlation between fitness magazines and women with a low body image, it seems that there would also be a connection between weight-obsessed gossip magazines such as Us Weekly and young women with a negative body image.

This research, which will focus on females between the ages of $18-24$, is being done to support the study that celebrity-obsessed tabloids help create a cultural climate that objectifies women. The study seeks to discover if the images of celebrities in mainstream media sources marketed to young women are causing negative effects on their readers, and if women are becoming more critical of others through the objectification, social comparison, and sociocultural theories.

\footnotetext{
${ }^{37}$ Turner, S.L., Hamilton, H., Jacobs, M. Angood, L.M., \& Dwyer, D.H. (1997.) "The Influence of Fashion Magazines on the Body Image Satisfaction of College Women: An Exploratory Analysis." Adolescence, 32 (127), 603+. Retrieved March 29, 2007, from .Questia database: http://www.questia.com/PM.qst?a=o\&d=500237108

${ }^{38}$ Ibid

${ }^{39}$ Ibid

${ }^{40}$ Malkin, A.R., Wornian, K., \& Chrisler, J.C. (1999). "Women and Weight: Gendered Messages on Magazine Covers." Sex Roles: A Journal of Research, 40 (7-8), 647+. Retrieved March 29, 2007, from Questia database $\mathrm{http} / /$ www.questia.com/PM.qst?a=o\&d=5001270637

${ }^{41}$ Gorrell, C. (2001). “Finding Fault.” Psychology Today, 34(5), 24. Retrieved Sunday, April 22, 2007 from the Academic Search Premier database.
} 


\section{THEORY}

Three theories tie in very closely with the research of body image: sociocultural theory, social comparison theory, and objectification theory.

Research on sociocultural theory explains that audiences feel pressured to conform to the cultural standards they see reflected in media images. ${ }^{42}$ The ultra-thin body types commonly assigned to women in the media are described as "western ideals." 43

A study conducted in Fiji that introduced westernized television programming in order to measure the direct impact of "western ideals" showed that audiences in Fiji experienced a negative body image and body dissatisfaction as a direct response to western media images. Immediately after watching television that displayed extremely thin models and actresses, young women living in Fiji started to have severe eating disorders and negative body image problems. ${ }^{44}$

Supermodel Kate Moss exemplifies the "western ideal" body type. Moss is a model that appears frequently on the covers of most popular fashion magazines, and is the face of international designers such as Calvin Klein and Louis Vuitton. A large part of Moss' notoriety comes from her famously underfed appearance. Visions of thin women with glamorous titles like "supermodel" lead to insecurities in the vast percentage of women who are not as thin as Kate Moss. ${ }^{45}$

Mass media is the single most powerful source for transmitting images of thinness to an audience. ${ }^{46}$ Sociocultural theory explains that constant exposure to images of an idealized thin body type will encourage young women to imitate those images, but there is one limitation to the theory. Not every young woman exposed to images of thin celebrities will develop an eating disorder. This theory does not explain how some women seem predisposed to body weight issues. ${ }^{47}$

\footnotetext{
42 Jung, J., \& Forbes, G. (2007, December). "Body Dissatisfaction and Disordered Eating Among College Women In China, South Korea and the United States: Contrasting Predictions From Sociocultural and Feminist Theories." Psychology of Women Quarterly, 31(4), 381-393. Retrieved January 7, 2008, from Academic Search Premier database.

${ }^{43}$ Ibid.

${ }^{44}$ Ibid

${ }^{45}$ Malkin, A.R., Wornian, K., \& Chrisler, J.C. (1999). Women and Weight: Gendered Messages on Magazine Covers. Sex Roles: A Journal of Research, 40 (7-8), 647+. Retrieved March 29, 2007, from Questia database.

${ }^{46}$ Willinge, A., Touyz, S., \& Charles, M. (2006, November). How do body-dissatisfied and body-satisfied males and females judge the size of thin female celebrities?. International Journal of Eating Disorders, 39(7), 576-582. Retrieved December 10, 2008.
} 
The next theory used to research body image is social comparison theory, which reasons that when a person is trying to assess their body, they compare themselves to other people. ${ }^{48}$ Sometimes this is done with peers and family, but a majority of the comparison is done with the people featured in mainstream media images. Readily available media, such as magazines, often tacitly encourage readers to engage in comparisons between themselves and images in the magazines. When differences are found, the observer has a desire to minimize the dissimilarities, including body weight. This method is known as social comparison theory, a theory often used to explain a negative body image and eating disorders. ${ }^{49}$

Research involving the effects of beauty magazines on women required female subjects to view a magazine and then describe the way it made them feel about their self-esteem. The results were often an internalization of the beauty standards glamorized in the advertisements by the female viewers. ${ }^{50}$ By internalizing, the women studied the models bodies and then judged them in comparison to their own physical forms. After doing a compare/contrast to their body shape, women generally felt worse about their appearance. This is an example of the social comparison theory. ${ }^{51}$

Social comparison theory is also believed to apply itself to physical beauty and eating habits. Theoretically if someone compares himself or herself to another person who is in an inferior situation, which in the context of this research would be bodies that skew from the dominant standard of beauty, self-esteem can be raised. Thus, if the person they are comparing themselves to be in a better situation (lower percentage of body fat or more developed musculature), their self esteem can be lowered. ${ }^{52}$ This is where the media has been blamed for its negative effect on self-esteem. This theory is sometimes used to explain the large numbers of young girls suffering from eating disorders. ${ }^{53}$

\footnotetext{
${ }^{47}$ Ibid.

${ }^{48}$ Corning, A., Krumm, A., \& Smitham, L. (2006, July). "Differential Social Comparison Processes in Women With and Without Eating Disorder Symptoms.” Journal of Counseling Psychology, 53(3), 338-349. Retrieved January 7, 2008, from PsycARTICLES database. 
Developing a harsher critical perspective on the bodies of others can also be studied through

objectification theory. ${ }^{54}$ This is applicable to the research of body image because it theorizes the objectification of the female body within the dominant culture, for example through the imagery displayed on the covers of popular magazines. Women in turn view these images and start to think of themselves as objects that require modification in order to be made presentable to the public. ${ }^{55}$ According to this theory, women often check their reflection and define themselves solely on external characteristics because they have learned that appearance is how a person should be judged. ${ }^{56}$

In gossip magazines women's bodies are analyzed by magnifying wrinkles or stretch marks, highlighting the slightest weight gain or loss. The bodies of famous women are objectified, but the magazines remain popular among readers.

Through objectification theory, women can sometimes develop anxiety and shame over their appearance if they deem themselves unsuitable according to media-influenced expectations. ${ }^{57}$ Women become aware of their own objectification and therefore start to control their appearance through attributes such as weight and hair color. Objectification theory provides a psychological link between the media's portrayal of beauty, and the direct effect it has on the population.

\section{RESEARCH QUESTIONS}

RQ1: Are women (18-24) from the state of West Virginia less likely to compare their bodies with celebrities found in magazines than women (18-24) from other states?

RQ2: Are women (18-24) who read celebrity-obsessed magazines more critical of other women's bodies?

H1: Women who read celebrity magazines are more critical of themselves and other women.

H2: Women from West Virginia read celebrity magazines less often than women from other states.

\footnotetext{
${ }^{54}$ Fredrickson, B. L., \& Roberts, T.-A. (1997). "Objectification theory: Toward understanding women's lived experiences and mental health risks.” Psychology of Women Quarterly, 21, 173-206.

${ }^{55}$ Ibid.

${ }^{56}$ Ibid.

${ }^{57}$ Ibid.
} 


\section{$\underline{\text { METHODOLOGY }}$}

To conduct my research I used a convenience sample. Convenience sampling is used in exploratory research when the researcher wants an inexpensive way to reach a sample of the population. As a student at West Virginia University, it was convenient to compile a sample of college-aged women to develop my research. Convenience sampling is often used during preliminary research efforts to get a gross estimate of the results, without the cost or time required to select a random sample. With my research this will be the best way to get results.

The primary unit of analysis in this study will be questions about the amount of celebrity magazines read. I will try and keep the research basic and manageable. I am looking to take smaller steps to reach a greater knowledge about the effects of celebrity-obsessed magazines on their female readership. The survey should answer questions regarding the negative or positive body image of the participant, their feelings about celebrity magazines, and whether they have become more critical of other women.

I gave the survey out to 289 people at West Virginia University; the amount of surveys that were returned and completed and used for research was 195 all from the Fall 2008 semester. The surveys used were broken down equally by the following Fall 2008 classes: Women's Studies (20\%), Journalism 101 (20\%), Broadcast News 215 (20\%), History 215 (20\%), and Math 121 (20\%). All surveys were completed and returned by women between the ages of 18-24. West Virginia residents made up 52.3 percent of the sample, and out of state residents made up 47.2 percent of the sample. A limitation of this research is that all women surveyed are in college at West Virginia University, living in or near Morgantown, WV.

\section{$\underline{\text { RESULTS }}$}

\begin{tabular}{|l|r|r|r|r|}
\multicolumn{2}{l|}{ WV } \\
\begin{tabular}{|ll|r|r|r|r|}
\hline & & & Cumulative \\
\hline Valid & RESIDENT & 102 & 52.3 & 52.6 & Percent \\
& NON-RESIDENT & 92 & 47.2 & 47.4 & 100.0 \\
& Total & 194 & 99.5 & 100.0 & \\
Missing & System & 1 & .5 & & \\
Total & & 195 & 100.0 & & \\
\hline
\end{tabular}
\end{tabular}

West Virginia female residents made up 52.3 percent of the convenience sample. West Virginia University is located in the northern part of the state and attracts many people throughout the United States. This was an ideal location for the survey to be conducted. 


\begin{tabular}{|c|c|c|c|c|c|}
\hline \multicolumn{6}{|c|}{ READCELEB } \\
\hline & & Frequency & Percent & Valid Percent & Cumulative \\
\hline \multirow[t]{6}{*}{ Valid } & \multirow{7}{*}{$\begin{array}{l}\text { STRONGLY AGREE } \\
\text { AGREE } \\
\text { MODERATE } \\
\text { SLIGHTLY DISAGREE } \\
\text { STRONGLY } \\
\text { DISAGREE } \\
\text { Total } \\
\text { Sotem }\end{array}$} & 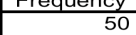 & $\begin{array}{r}25.6 \\
\end{array}$ & 25.8 & 25.8 \\
\hline & & 33 & 16.9 & 17.0 & 42.8 \\
\hline & & 48 & 24.6 & 24.7 & 67.5 \\
\hline & & 26 & 13.3 & 13.4 & 80.9 \\
\hline & & 37 & 19.0 & 19.1 & 100.0 \\
\hline & & 194 & 99.5 & 100.0 & \\
\hline Missing & & 1 & & & \\
\hline Total & & 195 & 100.0 & & \\
\hline
\end{tabular}

1. I like to read celebrity magazines such as Us Weekly, In Touch and Star:

Over 65 percent of women surveyed moderate to strongly agree with this statement. These results prove previous research on the popularity of celebrity-driven magazines, showing that they will not be disappearing anytime in the near future.

\begin{tabular}{|c|c|c|c|c|c|}
\hline \multicolumn{6}{|c|}{ UPTODATE } \\
\hline & & Frequency & Percent & Valid Percent & $\begin{array}{c}\text { Cumulative } \\
\text { Percent }\end{array}$ \\
\hline \multirow{6}{*}{ Valid } & STRONGLY AGREE & 27 & 13.8 & 14.0 & 14.0 \\
\hline & AGREE & 43 & 22.1 & 22.3 & 36.3 \\
\hline & MODERATE & 48 & 24.6 & 24.9 & 61.1 \\
\hline & SLIGHTLY DISAGREE & 40 & 20.5 & 20.7 & 81.9 \\
\hline & $\begin{array}{l}\text { STRONGLY } \\
\text { DISAGREE }\end{array}$ & 35 & 17.9 & 18.1 & 100.0 \\
\hline & Total & 193 & 99.0 & 100.0 & \\
\hline Missing & System & 2 & 1.0 & & \\
\hline Total & & 195 & 100.0 & & \\
\hline
\end{tabular}

2. I consider myself to be up to date on the latest celebrity news.

The majority of women are moderately up to date on celebrity news, surprising results considering the amount of readership.

CELEBOBSESS

\begin{tabular}{|ll|r|r|r|r|}
\hline & Frequency & Percent & Valid Percent & $\begin{array}{c}\text { Cumulative } \\
\text { Percent }\end{array}$ \\
\hline Valid & STRONGLY AGREE & 20 & 10.3 & 10.3 & 10.3 \\
& AGREE & 27 & 13.8 & 13.9 & 24.2 \\
& MODERATE & 27 & 13.8 & 13.9 & 38.1 \\
& SLIGHTLY DISAGREE & 39 & 20.0 & 20.1 & 58.2 \\
& STRONGLY & 81 & 41.5 & 41.8 & 100.0 \\
& DISAGREE & 194 & 99.5 & 100.0 & \\
& Total & 1 & .5 & & \\
Missing & System & 195 & 100.0 & & \\
Total & & & & & \\
\hline
\end{tabular}

3. I have bought celebrity-obsessed magazines for weight loss tips:

A majority of women strongly disagree; they do not look to celebrity- obsessed magazines for tips on weight loss. 


\begin{tabular}{|c|c|c|c|c|c|}
\hline & & Frequency & Percent & Valid Percent & $\begin{array}{c}\text { Cumulative } \\
\text { Percent }\end{array}$ \\
\hline \multirow[t]{6}{*}{ Valid } & STRONGLY AGREE & 66 & 33.8 & 34.2 & 34.2 \\
\hline & AGREE & 56 & 28.7 & 29.0 & 63.2 \\
\hline & MODERATE & 36 & 18.5 & 18.7 & 81.9 \\
\hline & SLIGHTLY DISAGREE & 22 & 11.3 & 11.4 & 93.3 \\
\hline & $\begin{array}{l}\text { STRONGLY } \\
\text { DISAGREE }\end{array}$ & 13 & 6.7 & 6.7 & 100.0 \\
\hline & Total & 193 & 99.0 & 100.0 & \\
\hline Missing & System & 2 & 1.0 & & \\
\hline Total & & 195 & 100.0 & & \\
\hline
\end{tabular}

4. I feel that celebrity-obsessed magazines put a spotlight on weight issues (negatively)

An overwhelming 66 percent of women agree that celebrity magazines negatively target weight issues.

\begin{tabular}{|c|c|c|c|c|c|}
\hline \multicolumn{6}{|c|}{ HAPPIER } \\
\hline & & Frequency & Percent & Valid Percent & $\begin{array}{c}\text { Cumulative } \\
\text { Percent }\end{array}$ \\
\hline \multirow[t]{6}{*}{ Valid } & STRONGLY AGREE & 62 & 31.8 & 32.0 & 32.0 \\
\hline & AGREE & 43 & 22.1 & 22.2 & 54.1 \\
\hline & MODERATE & 39 & 20.0 & 20.1 & 74.2 \\
\hline & SLIGHTLY DISAGREE & 34 & 17.4 & 17.5 & 91.8 \\
\hline & $\begin{array}{l}\text { STRONGLY } \\
\text { DISAGREE }\end{array}$ & 16 & 8.2 & 8.2 & 100.0 \\
\hline & Total & 194 & 99.5 & 100.0 & \\
\hline Missing & System & 1 & .5 & & \\
\hline Total & & 195 & 100.0 & & \\
\hline
\end{tabular}

5. I think I would be happier if I had a better body:

The majority of women surveyed strongly agree that they would be happier if they had a better body, 74.3 percent moderately to strongly agree with the statement.

\begin{tabular}{|ll|r|r|r|r|}
\multicolumn{7}{|c}{ DIET } \\
\hline & Frequency & \multicolumn{1}{c|}{ Percent } & Valid Percent & $\begin{array}{c}\text { Cumulative } \\
\text { Percent }\end{array}$ \\
\hline Valid & STRONGLY AGREE & 63 & 32.3 & 32.5 & 32.5 \\
& AGREE & 37 & 19.0 & 19.1 & 51.5 \\
& MODERATE & 38 & 19.5 & 19.6 & 71.1 \\
& SLIGHTLY DISAGREE & 23 & 11.8 & 11.9 & 83.0 \\
& STRONGLY & 33 & 16.9 & 17.0 & 100.0 \\
& DISAGREE & 194 & 99.5 & 100.0 & \\
& Total & 1 & .5 & & \\
Missing & System & 195 & 100.0 & & \\
Total & & & & & \\
\hline
\end{tabular}

\section{I think I should go on a diet:}

Over 60 percent of women surveyed agree with this statement, these results were anticipated considering that over $90 \%$ of women will diet at some point in their lifetime as previously stated in the research. 
TOOFAR

\begin{tabular}{|ll|r|r|r|r|}
\hline & Frequency & Percent & Valid Percent & $\begin{array}{c}\text { Cumulative } \\
\text { Percent }\end{array}$ \\
\hline Valid & STRONGLY AGREE & 75 & 38.5 & 38.9 & 38.9 \\
& AGREE & 50 & 25.6 & 25.9 & 64.8 \\
& MODERATE & 26 & 13.3 & 13.5 & 78.2 \\
& SLIGHTLY DISAGREE & 30 & 15.4 & 15.5 & 93.8 \\
& STRONGLY & 12 & 6.2 & 6.2 & 100.0 \\
& DISAGREE & 193 & 99.0 & 100.0 & \\
& Total & 2 & 1.0 & & \\
Missing & System & 195 & 100.0 & & \\
Total & & & &
\end{tabular}

8. I feel that the tabloid magazines go too far when taking private photos (example:

Jessica Simpson on a date):

A large majority surveyed believe that the paparazzi goes too far when taking private photos.

INCREASES

\begin{tabular}{|ll|r|r|r|r|}
\hline & Frequency & Percent & Valid Percent & \multicolumn{1}{c|}{ Cumulative } \\
& & 16 & 8.2 & 8.2 & 8.2 \\
Valid & STRONGLY AGREE & 21 & 10.8 & 10.8 & 19.1 \\
& AGREE & 40 & 20.5 & 20.6 & 39.7 \\
& MODERATE & 52 & 26.7 & 26.8 & 66.5 \\
& SLIGHTLY DISAGREE & 65 & 33.3 & 33.5 & 100.0 \\
& STRONGLY & 194 & 99.5 & 100.0 & \\
& DISAGREE & 1 & .5 & & \\
Missing & Total & System & 195 & 100.0 & \\
Total & & & \\
\hline
\end{tabular}

9. I feel that many pictures of celebrity flaws shown through gossip magazines

INCREASES my body confidence level:

Around 60 percent of young women surveyed slightly to strongly disagree with this statement.

COMPARE

\begin{tabular}{|ll|r|r|r|r|}
\hline & Frequency & Percent & Valid Percent & $\begin{array}{c}\text { Cumulative } \\
\text { Percent }\end{array}$ \\
\hline Valid & STRONGLY AGREE & 44 & 22.6 & 22.7 & 22.7 \\
& AGREE & 44 & 22.6 & 22.7 & 45.4 \\
& MODERATE & 38 & 19.5 & 19.6 & 64.9 \\
& SLIGHTLY DISAGREE & 34 & 17.4 & 17.5 & 82.5 \\
& STRONGLY & 34 & 17.4 & 17.5 & 100.0 \\
& DISAGREE & 194 & 99.5 & 100.0 & \\
& Total & 1 & .5 & & \\
Missing & System & 195 & 100.0 & & \\
Total & & & & \\
\hline
\end{tabular}


10. I am very conscious of my size and compare myself to the women in magazines:

The response to this question showed 65 percent of women surveyed moderate to strongly agree.

\begin{tabular}{|c|c|c|c|c|c|}
\hline \multicolumn{6}{|c|}{ THINK } \\
\hline & & Frequency & Percent & Valid Percent & $\begin{array}{l}\text { Cumulative } \\
\text { Percent }\end{array}$ \\
\hline \multirow{6}{*}{ Valid } & STRONGLY AGREE & 54 & 27.7 & 28.0 & 28.0 \\
\hline & AGREE & 46 & 23.6 & 23.8 & 51.8 \\
\hline & MODERATE & 34 & 17.4 & 17.6 & 69.4 \\
\hline & SLIGHTLY DISAGREE & 24 & 12.3 & 12.4 & 81.9 \\
\hline & $\begin{array}{l}\text { STRONGLY } \\
\text { DISAGREE }\end{array}$ & 35 & 17.9 & 18.1 & 100.0 \\
\hline & Total & 193 & 99.0 & 100.0 & \\
\hline Missing & System & 2 & 1.0 & & \\
\hline Total & & 195 & 100.0 & & \\
\hline
\end{tabular}

11. I think about my weight too often:

Almost 52 percent of women surveyed agree to strongly agree with this statement.

\begin{tabular}{|l|r|r|r|r|}
\multicolumn{7}{l|}{ TYRA } \\
\begin{tabular}{|ll|r|r|r|r|}
\hline & Frequency & Percent & Valid Percent & $\begin{array}{c}\text { Cumulative } \\
\text { Percent }\end{array}$ \\
\hline Valid & STRONGLY AGREE & 19 & 9.7 & 9.8 & 9.8 \\
& AGREE & 12 & 6.2 & 6.2 & 16.1 \\
& MODERATE & 17 & 8.7 & 8.8 & 24.9 \\
& SLIGHTLY DISAGREE & 30 & 15.4 & 15.5 & 40.4 \\
& STRONGLY & 115 & 59.0 & 59.6 & 100.0 \\
& DISAGREE & 193 & 99.0 & 100.0 & \\
Missing & Total & 2 & 1.0 & & \\
Total & System & 195 & 100.0 & & \\
\hline
\end{tabular}
\end{tabular}

12. I agree with the magazines when they call celebrities such as Tyra Banks and Jennifer Love Hewitt overweight:

Close to 60 percent strongly disagree with the medias perception of "overweight."

CRITICAL

\begin{tabular}{|ll|r|r|r|r|}
\hline & Frequency & Percent & Valid Percent & $\begin{array}{c}\text { Cumulative } \\
\text { Percent }\end{array}$ \\
\hline Valid & STRONGLY AGREE & 32 & 16.4 & 16.7 & 16.7 \\
& AGREE & 44 & 22.6 & 22.9 & 39.6 \\
& MODERATE & 53 & 27.2 & 27.6 & 67.2 \\
& SLIGHTLY DISAGREE & 34 & 17.4 & 17.7 & 84.9 \\
& STRONGLY & 29 & 14.9 & 15.1 & 100.0 \\
& DISAGREE & 192 & 98.5 & 100.0 & \\
& Total & 3 & 1.5 & & \\
Missing & System & 195 & 100.0 & & \\
Total & & & &
\end{tabular}

13. I feel that I have become more critical of other women's bodies as well as my own:

A majority of women feel moderate about this statement, contradicting my hypothesis. 
WV * READCELEB Crosstabulation

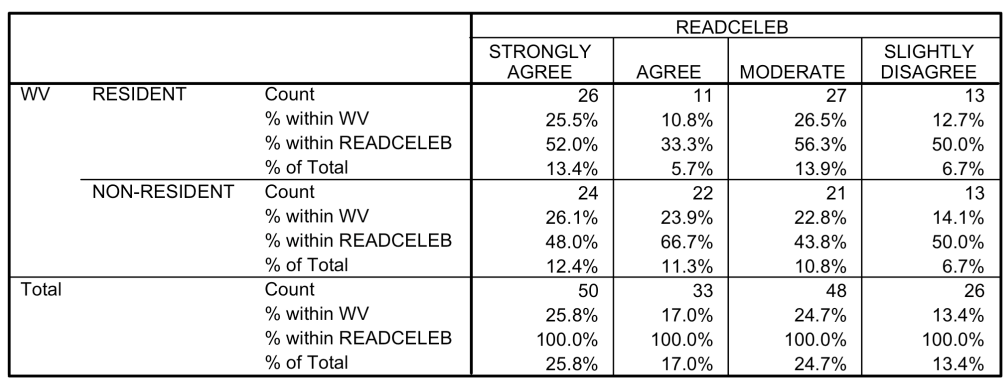

WV * CELEBOBSESS Crosstabulation

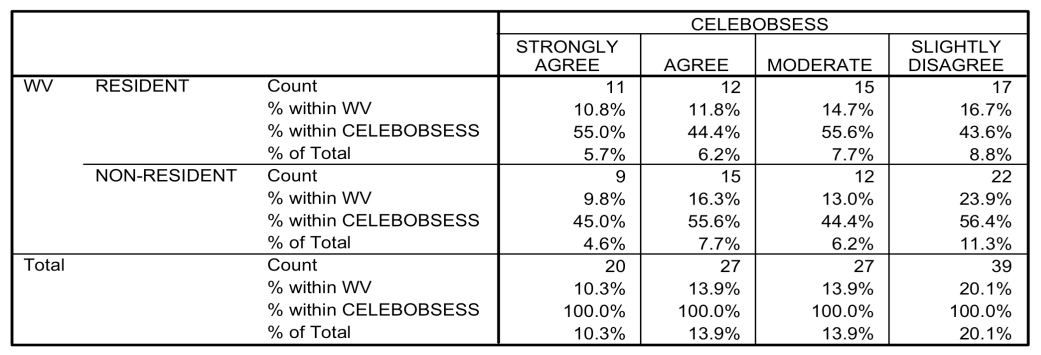

WV * HAPPIER Crosstabulation

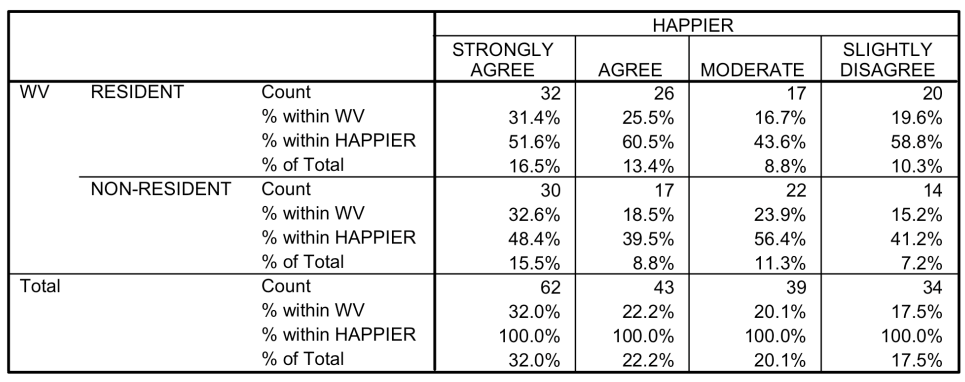


WV * COMPARE Crosstabulation

\begin{tabular}{|c|c|c|c|c|c|c|}
\hline & \multicolumn{4}{|c|}{ COMPARE } \\
\hline & & & $\begin{array}{c}\text { STRONGLY } \\
\text { AGREE }\end{array}$ & AGREE & MODERATE & $\begin{array}{l}\text { SLIGHTLY } \\
\text { DISAGREE }\end{array}$ \\
\hline \multirow[t]{8}{*}{ WV } & RESIDENT & Count & 24 & 23 & 16 & 21 \\
\hline & & $\%$ within WV & $23.5 \%$ & $22.5 \%$ & $15.7 \%$ & $20.6 \%$ \\
\hline & & $\%$ within COMPARE & $54.5 \%$ & $52.3 \%$ & $42.1 \%$ & $61.8 \%$ \\
\hline & & $\%$ of Total & $12.4 \%$ & $11.9 \%$ & $8.2 \%$ & $10.8 \%$ \\
\hline & NON-RESIDENT & Count & 20 & 21 & 22 & 13 \\
\hline & & $\%$ within WV & $21.7 \%$ & $22.8 \%$ & $23.9 \%$ & $14.1 \%$ \\
\hline & & $\%$ within COMPARE & $45.5 \%$ & $47.7 \%$ & $57.9 \%$ & $38.2 \%$ \\
\hline & & $\%$ of Total & $10.3 \%$ & $10.8 \%$ & $11.3 \%$ & $6.7 \%$ \\
\hline \multirow[t]{4}{*}{ Total } & & Count & 44 & 44 & 38 & 34 \\
\hline & & $\%$ within WV & $22.7 \%$ & $22.7 \%$ & $19.6 \%$ & $17.5 \%$ \\
\hline & & $\%$ within COMPARE & $100.0 \%$ & $100.0 \%$ & $100.0 \%$ & $100.0 \%$ \\
\hline & & $\%$ of Total & $22.7 \%$ & $22.7 \%$ & $19.6 \%$ & $17.5 \%$ \\
\hline
\end{tabular}

WV * CRITICAL Crosstabulation

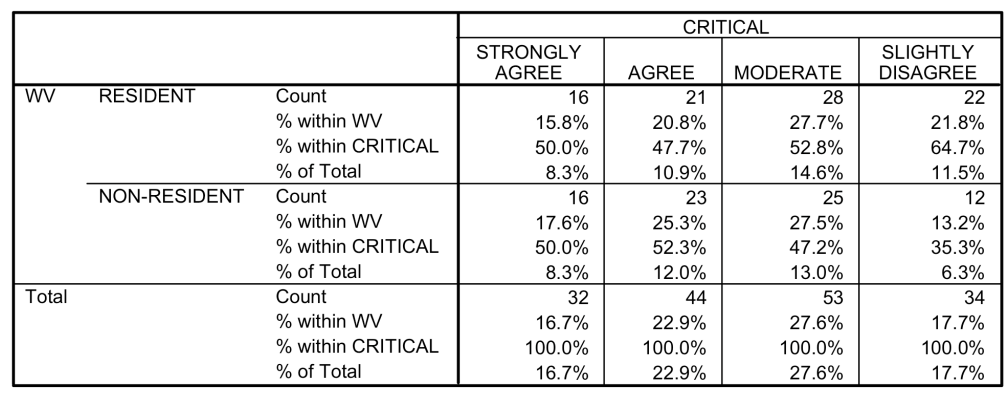

WV * TOOFAR Crosstabulation

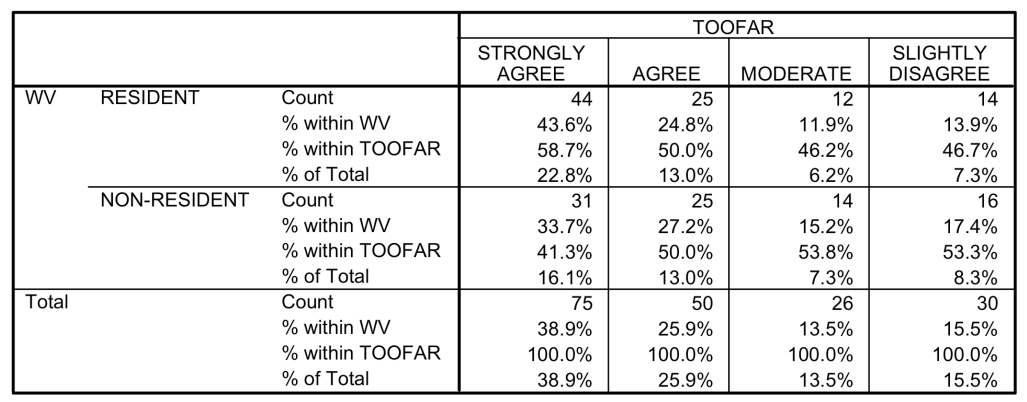

RQ1: Are women (18-24) from the state of West Virginia less likely to compare their bodies with celebrities found in magazines than women (18-24) from other states?

A: Women from the state of West Virginia are equally inclined to compare themselves to images found in celebrity-obsessed magazines compared with out-of-state residents. One hundred and two West Virginia 
residents, and ninety-two out-of state residents completed the survey and twelve percent of residents strongly agreed with this statement, while ten percent of non-residents felt equivalent. The following responses were within a three-percentile difference of in state compared to out-of-state residents. The results showed that a majority of women felt conscious of their size and compared themselves to women in magazines, but there was no significant difference between residents of West Virginia and women residing outside the state.

Although West Virginia has a high obesity rate it does not affect any comparable difference to the effects of celebrity-driven magazines between residents of West Virginia versus out-of state residents.

H2: Women from West Virginia read celebrity magazines less often than women from other states.

A: A nearly equal number of residents and non-residents strongly agree they read celebrity magazines regularly, around 13 percent of women surveyed. West Virginia residents agree with the statement less often than nonresidents ( 5 percent compared to 11 percent.) And West Virginia residents strongly disagree with the statement more often than non-residents (13 percent compared with 6 percent of non-residents.) These results are not significant enough to prove my hypothesis but more research could be conducted to find the reason that more women from West Virginia prefer not to read celebrity magazines compared to women from out-of-state. RQ2: Are women (18-24) who read celebrity-obsessed magazines more critical of other women's bodies? A majority of women who answered this question moderately to strongly agree that they have become more critical of their own bodies as well as the bodies of other women. However, the majority feels moderately about this statement. Moderate is sometimes used as "no comment" or "no opinion" therefore my hypothesis (H1: Women who read celebrity magazines are more critical of themselves and other women) was not proven. Sixteen percent of women strongly agreed and fifteen percent strongly disagreed with that statement.

This research proves the popularity of celebrity-driven magazines. A majority of participants considered themselves knowledgeable on celebrity issues and believe that they negatively focus on the body weight of celebrities. Women surveyed predictably wish for a better body but the majority do not purchase celebrity-driven magazines for weight loss tips.

A result that was unanticipated, celebrities shown having body flaws in magazines does not increase the self-esteem of the young women reading the magazines. According to Susan Bordo, a study of high school women showed a striking association between images of fashion models found in the media, and women feeling 
extremely ashamed and flawed of their own bodies. ${ }^{58}$ Because of the popularity of celebrity magazines and the abundance of research on fashion magazines and fitness periodicals showing perfect images of female bodies, the pictures of flawed bodies could have the opposite effect on women. The celebrity magazines prove that even the most beautiful women have flaws.

Although many young women who participated in my research do read celebrity-driven magazines (over 65 percent) many of them do not seem to be overly obsessed with their weight (only half think about their weight too often.) They do think the paparazzi and the media are erroneous when calling celebrities like Tyra Banks "fat" and a majority compare themselves with women idolized in magazine pages, but are not overly concerned.

These results prove previous studies that some women are predisposed to body image problems.

\section{IMPLICATIONS FOR FUTURE RESEARCH}

This research raises a number of questions that could lead to future research projects:

- Surveys of women between the ages of 25 and 40 could lead to different conclusions.

- More research could be done about the relationship between the number of magazines that promote weight loss and the overall obesity rate in the United States.

- Another future research topic could be the correlation between body image and eating disorders and their relationship to other psychological disorders such as obsessive-compulsive disorder, anxiety, and depression.

\section{SURVEY}

Dear Participant,

This survey is being conducted at West Virginia University. This research is being done as a requirement to receive a Master's Degree in Journalism. This study involves completion of a survey that will not take more than seven minutes. There is no right answer to these questions, and your responses will be completely anonymous. With that being stated, please be as honest as possible.

Any information that you provide in this survey is anonymous, your name is not required, and if the results of this study are published there will be no connection to you.

You do not have to take part in this research if you do not wish to. You may disregard this paper altogether or only answer one question if you prefer. If you refuse to answer the questions in the survey you will not receive any punishment or decrease in class participation. However, if you do participate I want to thank you for taking your time to help me research my area of interest to hopefully make a difference in the field of journalism.

If you have any questions regarding this study feel free to contact Sarah Young at syoung1@mix.wvu.edu.

\footnotetext{
${ }^{58}$ Bordo, Susan. “Unbearable Weight, Feminism, Western Culture, And the Body.”1995. 47-134.
} 
Thank You,

Sarah Young

Graduate Student

THIS SURVEY IS FOR WOMEN BETWEEN THE AGES OF 18-24 ONLY, PLEASE DISCARD THE SURVEY IF YOU DO NOT FIT THIS CATEGORY

Please circle the answer that best fits your opinion, if you do not have an opinion please leave the question blank Reminder: You do not have to answer all questions and have the right to refuse this survey at any time:

1= Strongly Agree 2= Agree 3=Moderate 4= Slightly Disagree 5= Strongly Disagree

* Please indicate what state (ex: WV, NY, KS, etc...) you grew up in:

1. I like to read celebrity magazines such as Us Weekly, In Touch and Star:

$\begin{array}{lllll}1 & 2 & 3 & 4 & 5\end{array}$

2. I consider myself to be up to date on the latest celebrity news:

$\begin{array}{lllll}1 & 2 & 3 & 4 & 5\end{array}$

3. I have bought celebrity-obsessed magazines for weight loss tips:

$\begin{array}{lllll}1 & 2 & 3 & 4 & 5\end{array}$

4. I feel that celebrity-obsessed magazines put a spotlight on weight issues (negatively):

$\begin{array}{lllll}1 & 2 & 3 & 4 & 5\end{array}$

5. I think I would be happier if I had a better body:

$\begin{array}{lllll}1 & 2 & 3 & 4 & 5\end{array}$

6. I think I should go on a diet:

$\begin{array}{lllll}1 & 2 & 3 & 4 & 5\end{array}$

7. I am at a healthy weight for my height:

$\begin{array}{lllll}1 & 2 & 3 & 4 & 5\end{array}$

8. I feel that the tabloid magazines go too far when taking private photos (example: Jessica Simpson on a date): $\begin{array}{lllll}1 & 2 & 3 & 4 & 5\end{array}$

9. I feel that many pictures of celebrity flaws shown through gossip magazines INCREASES my body confidence level:

$\begin{array}{lllll}1 & 2 & 3 & 4 & 5\end{array}$

10. I am very conscious of my size and compare myself to the women in magazines: 
$\begin{array}{lllll}1 & 2 & 3 & 4 & 5\end{array}$

11. I think about my weight too often:

$\begin{array}{lllll}1 & 2 & 3 & 4 & 5\end{array}$

12. I agree with the magazines when they call celebrities such as Tyra Banks and Jennifer Love Hewitt overweight:

$\begin{array}{lllll}1 & 2 & 3 & 4 & 5\end{array}$

13. I feel that I have become more critical of other women's bodies as well as my own:

$\begin{array}{lllll}1 & 2 & 3 & 4 & 5\end{array}$

\section{BIBLIOGRAPHY}

About Rodale: A Brief History: http://www.rodale.com/1,6597,1-101-211,00.html Accessed through Mens Health. Retrieved March 29, 2007.

Becker, A.E. "Television, disordered eating, and young women in Fiji. Negotiating body image and identity during rapid social change," 2004. Culture, Medicine, and Psychiatry, 28, 533-559.

Botta, R.A. "For Your Health? The Relationship between Magazine Reading and Adolescents' Body Image and Eating Disturbances," 2003. 389+

Bordo, Susan, “Unbearable Weight, Feminism, Western Culture, And the Body." London, England: University of California Press, 1995. 47-134.

Cash, T., \& Fleming, E. (2002, May). "The Impact of Body Image Experiences: Development of the Body Image Quality of Life Inventory.” International Journal of Eating Disorders, 31(4), 455-460.

Corning, A., Krumm, A., \& Smitham, L. (2006, July). "Differential Social Comparison Processes in Women With and Without Eating Disorder Symptoms," Journal of Counseling Psychology, 53(3), 338-349. Retrieved January 7 , 2008, from PsycARTICLES database.

Derbyshire, J. (2000, November 20). “The End of the Ectomorph - What Happened to the Skinny Male?” National Review, 52. Retrieved March 29, 2007, from Questia database.

"Focusing on Body Image Dissatisfaction," Society for the Advancement of Education, (1999, February). USA Today Magazine, Retrieved February 24, 2008, from Academic Search Premier database.

Fredrickson, B. L., \& Roberts, T.A. (1997). “Objectification theory: Toward understanding women's lived experiences and mental health risks," Psychology of Women Quarterly, 21, 173-206.

Gorrell, C. (2001) "Finding Fault," Psychology Today, 34(5), 24. Retrieved Sunday, April 22, 2007 from the Academic Search Premier database.

Graham, Michelle, (2005) “Wanting To Be Her, Body Image Secrets Victoria Won't Tell You”. Illinois, InterVarsity Press, 21-82. 
Harris, D. (2008, January) “Celebrity Bodies,” Southwest Review, 93(1), 135-144. Retrieved December 10, 2008, from Academic Search Complete database.

Jung, J., \& Forbes, G. (2007, December). "Body Dissatisfaction and Disordered Eating Among College Women In China, South Korea and the United States: Contrasting Predictions From Sociocultural and Feminist Theories." Psychology of Women Quarterly, 31(4), 381-393. Retrieved January 7, 2008, from Academic Search Premier database.

Ko, M. (2001, October 8). "Blessed are the emaciated". Report / Newsmagazine (BC Edition), 28(19), 38. Retrieved January 11, 2008, from Academic Search Premier database.

Komperda, J. "Ab-solutely fabulous ... but almost impossible to achieve". St. Louis Post-Dispatch (MO), Retrieved Sunday, April 22, 2007 from the Newspaper Source database.

Labre, M. (2005). "Burn fat, build muscle: A content analysis of Men's Health and Men's Fitness". International Journal of Men's Health, 4(2), 187-200. Retrieved Wednesday, March 28, 2007

Malkin, A.R., Wornian, K., \& Chrisler, J.C. (1999). "Women and Weight: Gendered Messages on Magazine Covers". Sex Roles: A Journal of Research, 40 (7-8), 647+. Retrieved March 29, 2007, from Questia database.

Maltby, J., Giles, D., Barber, L., \& McCutcheon, L. (2005, February). "Intense-personal celebrity worship and body image: Evidence of a link among female adolescents". British Journal of Health Psychology, 10(1), 17-32. Retrieved February 8, 2008, from Women's Studies International database.

Markey, C. N., \& Markey, P.M. (2005.) "Relations between Body Image and Dieting Behaviors: An Examination of Gender Differences”. Sex Roles: A Journal of Research, 53 (7-8), 519+. Retrieved March 29, 2007.

Morry, M., \& Staska, S. (2001). "Magazine exposure: Internalization, self-objectification, eating attitudes, and body satisfaction in male and female university students". Canadian Journal of Behavioural Science, 33(4), 269-279. Retrieved Sunday, April 22, 2007 from the PsycARTICLES database.

Murnen, S. K., Smolak, L., Mills, J. A., \& Good, L. (2003). "Thin, Sexy Women and Strong, Muscular Men: GradeSchool Children's Responses to Objectified Images of Women and Men”. Sex Roles: A Journal of Research, 49(9-10), 427+. Retrieved March 29, 2007, from Questia database.

Murray, S. H., Touyz, S. W., \& Beumont, P. J. V. (1996). "Awareness and perceived influence of body ideals in media: A comparison of eating disorder patients and the general community". Eating Disorders, 4, 33-46.

Petrie, T. A., Austin, L. J., Crowley, B. J., Helmcamp, A., Johnson, C. E., Lester, R., Rogers, R., Turner, J., \& Walbrick, K. (1996). "Sociocultural explanations of attractiveness for males". Sex Roles, 35, 581-602.

"Reality Check With Ashley Borden". (2007, January). American Fitness, Retrieved January 11, 2008, from Academic Search Premier database.

Stice, E., Schupak-Neuberg, E., Shaw, H. E., \& Stein, R. I. (1994). "Relation of media exposure to eating disorder symptomatology: An examination of mediating mechanisms". Journal of Abnormal Psychology, 103, 836-840.

Strong, K., Parks, S., Anderson, E., Winett, R., \& Davy, B. (2008, October). "Weight Gain Prevention: Identifying Theory-Based Targets for Health Behavior Change in Young Adults". Journal of the American Dietetic Association, 108(10), 1708-1715. Retrieved December 5, 2008.

Tan, M., \& Mascia, K. (2007, December 17). “Jennifer Love Hewitt FIRES BACK”. (Cover story). People, 68(25), 5971. Retrieved January 10, 2008, from Academic Search Premier database. 
Thompson, J. K., \& Tantleff, S. (1992). "Female and male ratings of upper torso: Actual, ideal, and stereotypical conceptions". Journal of Social Behavior and Personality, 7, 345-354.

Turner, S.L., Hamilton, H., Jacobs, M. Angood, L.M., \& Dwyer, D.H. (1997.) “The Influence of Fashion Magazines on the Body Image Satisfaction of College Women: An Exploratory Analysis”. Adolescence, 32 (127), 603+. Retrieved March 29, 2007, from .Questia database.

Wenner Media, “http://www.srds.com/mediakits/us_weekly/demographics.html."”

Wheeler, L. \& Miyake, K. (1992). "Social comparison in everyday life". Journal of Personality and Social Psychology, $62,760-773$. Description of theory found in this article.

Willinge, A., Touyz, S., \& Charles, M. (2006, November). "How do body-dissatisfied and body-satisfied males and females judge the size of thin female celebrities?” International Journal of Eating Disorders, 39(7), 576-582. Retrieved December 10, 2008, doi:10.1002/eat.20278

Wulff, J., Adato, A., Baker, K., Dagostino, M., Ehrich, K., Seaman, D., et al. (2004, July 26). "Pressure To Be Perfect". People, 62(4), 72-78. 